\title{
Study on Clinical, Histopathological Features and Evaluation Results of Skin Cancer Treatment in Can Tho Oncology Hospital
}

\author{
Penelitian pada Fitur Klinis, Histopatologis dan Hasil Evaluasi Pengobatan \\ Kanker di Rumah Sakit Onkologi Can Tho
}

Nguyen Van Qui*, Phan Nguyen Ngoc** *Can Tho Oncology Hospital, Can Tho City, Vietnam, **Department for Planning, Can Tho Psychiatric Hospital,
Can Tho City, Vietnam

DOI: http://dx.doi.org/10.21109/kesmas.v10i3.946

\begin{abstract}
Skin cancer as the most common cancer diagnosis tend to be increasing. This condition is a particularly significant issue in developed countries. This study aimed to describe the clinical features, histopathological features, complications, and early surgical treatment outcomes of skin cancer in Can Tho Oncology Hospital from 2014 to 2015. This descriptive prospective study involved all patients with non-melanoma skin cancer that were examined and treated at Can Tho Oncology Hospital from July 2014 to March 2015. There were 78 cases selected. Skin cancer was found to be more common among older patients. The prevalence of basal cell carcinoma was found higher than squamous cell carcinoma with percentage worth $76.9 \%$ and $23.1 \%$ respectively. Worth $73.1 \%$ of all the patients in the study underwent surgery with wide resection and reconstruction. In this study, most patients were the elderly. The basal cell carcinoma was the most common. The main treatment was surgery with wide resection and reconstruction. The complication was rare $1.3 \%$ with skin flap necrosis.

Keywords: Basal cell carcinoma, clinical features, histopathology, skin cancer, squamous cell carcinoma
\end{abstract}

\footnotetext{
Abstrak

Kanker kulit, diagnosis kanker paling umum, cenderung mengalami peningkatan. Kondisi ini secara khusus merupakan isu penting di negara-negara maju. Penelitian ini bertujuan untuk mendeskripsikan fitur klinis, fitur hispatologis, komplikasi dan hasil pengobatan bedah awal kanker kulit di Rumah Sakit Onkologi Can Tho dari tahun 2014 sampai 2015. Penelitian deskriptif prospektif ini melibatkan seluruh pasien dengan kanker kulit nonmelanoma yang diuji dan diobati di Rumah Sakit Onkologi Can Tho dari Juli 2014 sampai Maret 2015. Terdapat 78 kasus terpilih. Kanker kulit ditemukan lebih umum pada pasien yang lebih tua. Prevalensi karsinoma sel basal ditemukan lebih tinggi dibandingkan karsinoma sel skuamosa dengan
}

persentase masing-masing 76,9\% dan $23,1 \%$. Sebesar $73,1 \%$ dari seluruh pasien dalam penelitian ini menjalani bedah dengan rekonstruksi dan reseksi yang lebar. Dalam penelitian ini, sebagian besar pasien adalah lanjut usia. Karsinoma sel basal adalah yang paling umum. Pengobatan utama adalah bedah dengan rekonstruksi dan reseksi yang lebar. Komplikasi jarang terjadi 1,3\% dengan nekrosis lipatan kulit.

Kata kunci: Karsinoma sel basal, fitur klinis, histopatologi, kanker kulit, karsinoma sel skuamosa

\section{Introduction}

Skin cancer, as the most common cancer diagnosis tend to be increasing. This condition is a particularly significant issue in developed countries. In Australia, the incidence of squamous cell carcinoma (SCC) is so far the highest in the world over 1,000 cases per 100,000 residents. ${ }^{1}$ In Vietnam, the number of the outpatient and inpatient witnessed the upward trend as the data in 2010 showed an increase by $2.6 \%$ than in $2007 .^{2}$ In Can Tho City, skin cancer ranked the second among 10 most common cancers in term of gender. ${ }^{3}$ Long term of sun exposure has mainly caused skin cancer. However, there are few studies to address the recent clinical features as well as histopathological features of skin cancer. The study aimed to explore the clinical features, histopathological features, complications of patients with skin cancer and early surgical treatment outcomes of skin cancer in Can

Correspondence: Phan Nguyen Ngoc, Department for Planning, Can Tho Psychiatric Hospital, 37 /2 Street, Hung Loi Ward, Ninh Kieu District, Can Tho City,Vietnam, Phone: 84967251019,e-mail: pnngocctump@gmail.com 
Tho Oncology Hospital from 2014 to 2015.

\section{Method}

Medical records for all skin cancer patients as confirmed by histologist that had surgery at Can Tho Oncology were identified. This descriptive study evaluated the primary outcomes of surgery by following up the patients about complications after surgery, free margin and functional and aesthetic primary results. Medical records were for 78 patients with basal cell carcinoma (BCC) and SCC. The 78 patients variable included gender, age, occupation, residence, period of the disease, the main complaints, prominent skin lesions, site of these lesions and the rate of histological type as well as the stage of the skin cancer. This study examined the patients and collected the records together with necessary laboratory tests. After that, this study had a diagnostic about the stage of the skin cancer. According to the clinical protocol, if the patients did not have any underlying disease or those under good control, the patients may undergo the surgery. The method of surgery would mainly depend on the site of lesion, the stage of disease, the general health of patient, the histological type and other factors.

Study tools used were the medical record paper in Can Tho Oncology Hospital and the inquiry. Data was analyzed using software Statistical Package for the Social Sciences (SPSS) version 18.0. The entire patients who received the explanation for the aim of the study took part voluntarily.

\section{Results}

There were 78 patients with skin cancer included. Skin cancer frequently occured in the over 60 aged groups, with the highest percentage $71.7 \%$. The oldest patient was 101 years old. The mean aged was 72 years old. The male/female ratio was 0.9 . The majority of the patients work as a farmer, which was illustrated by $91 \%$. Worth $66.7 \%$ of the patients lived in rural areas.The chief complaint: the most popular complaint was ulceration $(34.6 \%)$, closely followed by itching $(25.6 \%)$. Face and neck skin were the most common sites worth 66 . $7 \%$. Particularly, the carcinoma on the face skin mostly located on around the nose and cheek (57.9\%). BCC was the most common skin cancer by $76.7 \%$, followed by squamous cell carcinoma by $23.1 \%$. BCC had an onset time of over one year in $70 \%$ of cases. SCC had an onset time of less than one year in $56.6 \%$ of cases (Table 1 ).

Worth $70 \%$ of tumors in the scalp and $94.2 \%$ face and neck skin were found to be BCC and 70\% of tumors found on the skin of the limbs were found to be SCC (Table 2). Worth $90 \%$ of BCC case the tumors were under five centimeter diameter and $29 \%$ of the SCC case were more the tumors than five centimeter (Table 3).

The main treatment for skin cancer is surgery with
Table 1. The Correlation between The Histophatological Type and Duration

\begin{tabular}{lll}
\hline The Duration & BCC (\%) & SCC (\%) \\
\hline Under 1 year & $17(30)$ & $10(56.6)$ \\
From 1 to 5 years & $32(53.3)$ & $4(22.2)$ \\
From 5 to 10 years & $6(10)$ & $3(16.7)$ \\
Over 10 years & $4(6.7)$ & $1(5.6)$ \\
\hline Total & $\mathbf{5 9 ( 1 0 0 \% )}$ & $\mathbf{1 8 ( 1 0 0 \% )}$ \\
\hline
\end{tabular}

Table 2. The Correlation between The Histophatological Type and Site

\begin{tabular}{lll}
\hline Variable & BCC (\%) & SCC (\%) \\
\hline Scalp & 70 & 30 \\
Face and neck skin & 94.2 & 5.8 \\
Limb skin & 30 & 70 \\
Trunk skin & 17 & 83 \\
\hline
\end{tabular}

Table 3. The Correlation between The Histopathological Type and Size of Tumor

\begin{tabular}{lll}
\hline Size of Tumor & BCC (\%) & SCC (\%) \\
\hline Tumor diameter (TD) $\leq 2 \mathrm{~cm}$ & 53.3 & 7.8 \\
TD from 2 to $5 \mathrm{~cm}$ & 36.7 & 50 \\
TD $\geq 5 \mathrm{~cm}$ & 5 & 22.2 \\
Tumor invades the muscle, bone & 5 & 0 \\
\hline Total & $\mathbf{1 0 0 \%}$ & $\mathbf{1 0 0} \%$ \\
\hline
\end{tabular}

wide resection and reconstruction by skin flap. This was illustrated by $73.1 \%$. Another method is surgery with wide resection and reconstruction. Worth $1.3 \%$ patients experienced the skin graft. Complication such as skin flap necrosis was noted in one case $(1.3 \%)$. Worth $9 \%$ of patients was found positive in an area cut and $85.7 \%$ of these area cuts occurred in the face and neck. All patients were interviewed upon discharge from the hospital and $92.3 \%$ reported that their functions and aesthetics after surgery were very good.

\section{Discussion}

This study had recorded that $73.1 \%$ of patients were over 60 years old. The mean age was 72 years old. From that point, it is considered that the elderly was one of the skin cancer etiology. The explanation was long term exposing the sun light. In addition to this, the ability to fix the genetic mutation was weakening. ${ }^{4}$

In term of the main complaint, the most popular complaint was ulceration $(34.6 \%)$, closely following itching $(25.6 \%)$. A smaller percentage was accounted by pain $(5.1 \%)$. According to the author Nguyen Dai Binh, the symptoms that warn the skin cancer is ulceration. However, most of patients did not have painful symptoms, which might be the reason why they admit the hospital at the late stage..$^{5}$ According to the author Kyle, itch was the most common symptom reported in both skin cancers $(43.5 \%$ of SCCs and $33.4 \%$ of BCCs). The 
prevalence of pain was $39.8 \%$ in SCC and $17.7 \%$ in BCC. Their findings revealed that pain and itch were common symptoms of non-melanoma skin cancer. ${ }^{6}$

Face and neck skin were the most common sites worth $66.7 \%$. Particularly, in the face skin, the carcinoma was mostly located around the nose and cheeks (57.9\%). It was $70 \%$ BCC patients who had period over one year, while the SCC patients had shorter period by $56.6 \%$ patients less than one year. The natural record of BCC is that of the slowly enlarging. In term of BCC, the size of the tumor is under five centimeter nearly $90 \%$ and no case was reported nodal metastasis. In another study, SCC had a rapid growth by $45 \%$ patients who had period under one year. ${ }^{2}$ This study noted that $5.6 \%$ cases were nodal metastasis in comparison to other studies, the rate of nodal metastasis was higher by $18 \% .^{7}$ The discrepancy is the aim of the study and the study population. This study also collected the entire skin cancer patients confirmed by histologist.

Wide resection and reconstruction by skin flaps were performed by $71.8 \%$. The methods of surgery were complicated, which depended on the site and the size of tumor. Worth $9 \%$ of unsafe border reported in this study was mainly located in the face and neck skin. In contrast, other studies declared the lower rate in unsafe border. The explanation is that the mean diameter of the tumor in this study was two centimeter smaller. ${ }^{8-10}$ Another explanation was this study had been conducted recently, meanwhile health care system was in more improvement. In addition, physicians also had a variety of choices with antibiotics. The primary results of aesthetic and function were excellent $(92.3 \%)$. A complication such as skin flap necrosis was noted in one case $(1.3 \%)$.

\section{Conclusion}

This study finds that skin cancer is frequently diagnosed late in the patient's life as most of patients are el- derly. Therefore, the early detection should be encouraged. BCC is the most common skin cancer, but this type has long period. The main treatment is surgery with wide resection and reconstruction. Complication such as skin flap necrosis is rare at only $1.3 \%$.

\section{References}

1. Lomas A, Leonardi-Bee J. A systematic review of worldwide incidence of nonmelanoma skin cancer. British Journal of Dermatology. 2012; 166: 1069-80.

2. Ha VT, Sau NH, Minh L. Study on distribution of skin cancer at the national dermatology 2007-2010. Journal of Practical Medicine. 2011; 777(8), p. 33-35.

3. Thang HQ. Population based registry of cancers in Can Tho City during the year 2005-2007. Y Hoc Thanh Pho Ho Chi Minh. 2009; 13(5), p. $43-$ 52.

4. Vu Thai Ha, Nguyen Thu Hien, Nguyen Huu Sau. Study on the clinical features, histopathological findings of patients with squamous cell carcinoma at Internation Hospital of dermato-verenology 2007-2012. Journal of Milititary-Pharmaco Medicine. 2014; 2.

5. Binh ND. Surgery for skin cancer, surgery for cancer. Ha Noi: Ha Noi Medical Publishing Hourse; 2010.

6. Mills KC, Kwatra SG, Feneran AN. Itch and pain in nonmelanoma skin cancer: pain as an important feature of cutaneous squamous cell carcinoma. JAMA Dermatology. 2012; 148 (12).

7. Pham Hung Cuong. Nodal involvement of squamous cell carcinoma in the skin of extremities: Y Hoc Thanh Pho Ho Chi Minh. 1998; 2(3): 2925.

8. To Quang Huy, Trinh Hung Manh, Tran Van Tuan. Epithelioma carcinoma-some clinical features, histopathological finding and surgical treatment. Journal of Practical Medicine. 2011; 5 (764): 7-9.

9. Tran Thanh Cuong, Vo Dang Hung, Bui Xuan Truong. Local flaps in reconstruction in treatment of facial skin cancer. Vietnam Oncology Journal. 2007; 2: 28-35.

10. Bui Xuan Truong, Nguyen Anh Khoi, Le Hanh. Wide excision- reconstruction in treatment of facial skin cancer: functional, aesthetic and oncologic results. Y Hoc Thanh Pho Ho Chi Minh. 2010; 14 (4): 207-16. 